\title{
Cultivating the soft skills of future construction managers through restorying construction workers' career narratives
}

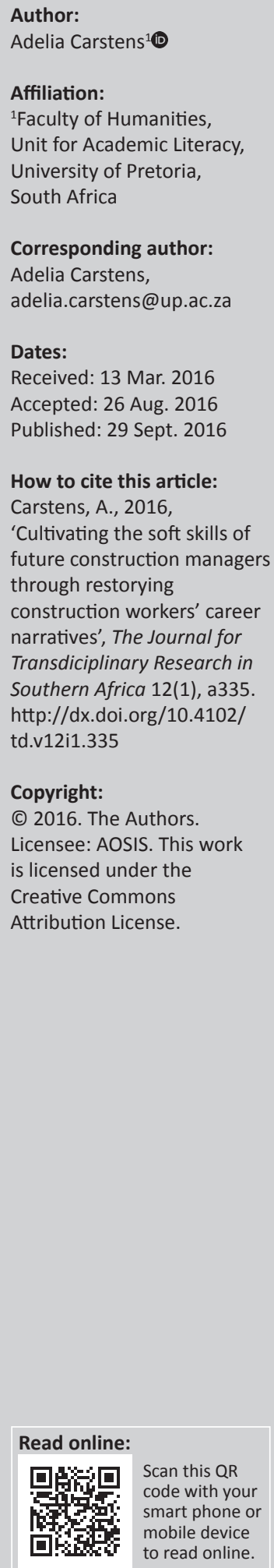

Background: In the construction industry, there is an increased awareness of the importance of soft skills. However, no empirical studies have been conducted on the effectiveness of pedagogical strategies in higher education to improve the soft skills of future construction managers.

Aim: The main aim of the research was to explore how undergraduate students of the construction sciences construe the identities of construction workers and whether their views have been changed through their retelling of and reflecting on the career stories of these workers. It was anticipated that the results would give an indication of whether the students' 'soft skills' can be improved through curricular interventions.

Setting: The research was situated in a module on academic and professional literacy for students of Construction Economics at a large residential university in Gauteng. The module serves as an adjunct to a core module in Building Science.

Methods: Theoretically, the article is underpinned by Critical Multicultural Education, and methodologically, it is based on theories of narratives and storytelling. The primary instruments of data gathering were students' narrative reconstructions of the career stories of construction workers that were gathered through personal interviews. The student narratives were analysed using the qualitative data analysis program AtlasTi.

Results: Four themes emerged from the analysis of the narratives - personal characteristics, sponsors/enablers, challenges and agency - while the analysis of students' critical reflections on their narratives pointed towards an understanding that career success is determined by diligence and work ethics, rather than circumstances.

Conclusion: An important change that occurred in students' perceptions about construction workers is a realisation that successful workers are driven by an internal locus of control and are not derailed by adverse circumstances. The changed attitudes go beyond tolerance and reduced stereotyping. It is recommended that in order to deliver well-rounded graduates to the construction industry, multiple opportunities should be created in the curricula for modules focused on the acquisition of 'hard' as well as 'soft' skills.

\section{Introduction}

Well-rounded professionals (professionals with 'hard' as well as 'soft' skills) in the built environment are of the utmost importance to provide infrastructure necessary to support economic well-being and quality of life in the modern world (Othman 2014:5).

In the construction industry, 'hard skills' primarily refer to knowledge of and the ability to apply construction methods and techniques and the ability to perform cost estimation techniques such as preparation of tenders (SACPCMP n.d.:39-40). 'Soft skills' include abilities that can be broadly categorised as personal attributes (self-management skills, emotional intelligence, stress management skills, workplace ethics and workplace professionalism); interpersonal skills (communication skills, collaboration skills, workplace diversity skills, cultural knowledge and social intelligence); and problem-solving and decision-making skills (conflict resolution skills as well as planning and organising skills) (Hager, Cowly \& Garrick 2000; Mahasneh \& Thabet 2015; Shakir 2009). 
Soft skills have become increasingly important in the construction industry, because it is rapidly moving from an industry focused on the delivery of technical services to a service industry that competes in the global marketplace (Shakir 2009:309). However, in Wilson's (2013) opinion, the culture in the construction industry is still a matter of 'Do as I say, not as I do', which may be caused by too great an emphasis on a command and control style, at the expense of motivation, engagement, communication and coaching, and the benefits they can bring. For construction managers, engagement and motivation of others are of particular importance, because they 'have to determine what drives people to exhibit certain behaviour, what directs or channels people's behaviour, and how the behaviour is sustained' (Sunindijo \& Zhou 2013:99).

The construction industry has become more reliant on tertiary education and training programmes to supply the work force for an increasingly complex and demanding work environment (Bilbo et al. 2000). However, employers are still concerned about the low level of these skills among newly hired construction graduates (Ahn, Annie \& Kwon 2012). One of the major causes of the 'skills gap' that has been confirmed by the literature-based research of Mahasneh and Thabet (2015) is that 'The existing construction education curriculum cannot sufficiently support students to cultivate soft skills competencies to match the industry's needs'. Othman (2014:5) agrees that universities are not doing enough, nor are they on par with the standards demanded by industry, in particular with regard to producing well-rounded graduates with technical knowledge as well as being flexible and adaptable. Othman (2014) quotes Rwelamila (2007) who found that most present-day construction management courses are dominated by a technical skills base with little or no social cultural knowledge base.

In South African higher education there is an increased awareness of the importance of soft skills. Firstly, soft skills are explicitly mentioned in the graduate outcomes specified by the South African Council for the Project and Construction Management Professions, who accredits degrees in construction in South Africa (n.d.:39-40). These outcomes include 'understand $[i n g]$ socio-economic issues affecting construction and [the] project environment' and 'knowledge of written and oral communication in the construction environment' as two of the eight outcomes for these degrees. Secondly, the Department of Construction Economics at the institution where this research took place reiterated the importance of teaching both language and interpersonal skills in the module on academic and professional literacy, which is a compulsory module for all students of Real Estate, Construction Management and Quantity Surveying (Van Heerden 2016).

In the business environment, narratives have been successfully used to promote the development of soft skills as well as knowledge transfer. Published research studies on storytelling in business organisations include Boje's (1991) study in a large office-supply firm in the United States on how people perform storytelling to make sense of events, introduce change and gain political advantage during conversations; Meyer's (2004) investigation into the use of narrative as a medium for knowledge transfer in small teams in the United Kingdom; and Tobin's (2006) research into the use of stories and storytelling as knowledge-sharing practices in the mining industry in South Africa. A fairly recent study presents cases of storytelling applications in construction projects and suggests that the storytelling approach should be widely applied in the construction industry (Leung \& Fong 2011:480).

However, no empirical studies have been found on the use of narratives in formal training programmes to promote the development of soft skills. Although the above-mentioned studies touch on the implications of using narratives in training contexts, none of them have been conducted in formal tertiary education settings. In addition, they lack clear pedagogical frameworks and educational approaches.

Critical Multicultural Education offers a viable framework for pedagogy as well as research on soft skills training that makes use of narrative methodologies. Critical Multiculturalism in education seeks to create an open and culturally diverse education. It conceptualises culture as dialectical and full of tensions, rather than coherent, orderly and predictive (Kubota 2004:39) and recognises that all individuals take part in the cultural production of domination and subordination. Furthermore, Critical Multicultural Education celebrates 'border knowledge', as opposed to canonical knowledge (Rhoads 1995). Border knowledge is the knowledge that culturally diverse students (mostly those located on society's margins) bring to the university. In an extended sense, border knowledge could also include the knowledge that workers on the margins of a profession bring to that profession.

Critical Multicultural Education is closely linked to servicelearning approaches in Higher Education, as expounded by Boyle-Baise (2002:5). Service-learning strongly correlates with tolerance, personal development and linking the university experience to the community (Einfeld \& Collins 2008:96) through considering the perspectives of 'those who are disenfranchised and marginalised in society' (Boyle-Baise 2002:4). When students start understanding local issues from a different perspective, they are likely to develop multicultural competence. This should in turn lead to a reduction in negative stereotypes and an increase in tolerance for diversity (Eyler \& Giles 1999).

To explore the issue of curricular support in cultivating soft skills in a diverse workplace - within the framework of Critical Multicultural Education - the following research questions were asked:

1. How do students pursuing degrees in the construction sciences construe the identities of construction workers with no formal qualifications? 
2. How are students' perceptions about the identities of construction workers changed as a result of engagement around the construction workers' life stories?

Question 1 was aimed at providing students of the construction sciences with a method or tool to better understand construction workers socially and culturally and what may drive them to exhibit certain behaviour (Sunindijo \& Zhou 2013:99), which should then ideally equip the students to build better relationships with workers on site; whereas question 2 was aimed at exploring what students thought they had learnt about the construction workers through the interviews and their restorying of the content.

\section{Research methods and design Study design}

Narrative inquiry was considered to be an appropriate methodological paradigm for the research. As a research method in the social sciences, it has been established through the work of scholars such as Polanyi (1989), Lieblich, Mashiach-Tuval and Zilber (1998), and Clandinin and Connelly (2000); and as a method in educational and applied linguistics research, it ties in with the so-called '(auto) biographical turn' (Pavlenko 2007). Its application in applied linguistics is comprehensively documented by Pavlenko (2007), De Fina and Georgakopolou (2012) and Barkhuizen (2013). Within this paradigm, narrative research is regarded both as a social activity (Steier 1991) and as a sense-making activity (Ochs \& Capps 2001). Barkhuizen (2013:4) embeds these two components in the notion of 'narrative knowledging', which is 'the meaning making, learning, or knowledge construction that takes place during the narrative research activities of (co)constructing narratives, analysing narratives, reporting the findings, and reading/watching/ listening to the research reports'. Narrative knowledging allows narrative inquiry to take place at two levels: the construction of narratives out of non-narrative data and qualitative analysis of narratives. Polkinghorne (1995) refers to this distinction as 'narrative analysis' and 'analysis of narratives', respectively, which can be related to Bruner's (2006) distinction between 'narrative cognition' and 'paradigmatic cognition'. Barkhuizen (2013:12) explains that narrative analysis entails 'the temporal organization of experience, while seeking context-sensitive explications' in other words, synthesising experiences into a narrative whole - while the analysis of narratives entails 'classifying a particular instance as belonging to a category or concept'. Narratives are analysed through coding for themes, categorising them and looking for relationships between the themes.

In alignment with Critical Multicultural Education, I intended to conduct narrative research with a transformative aim (Denzin \& Giardina 2009). Narrative research has the potential to challenge the interests of the powerful by foregrounding the voices of those who are traditionally seen as the objects of research and as beneficiaries of Western expertise, materials and methods (Rubdy 2009). The purpose of narrative inquiry within a transformative paradigm is to reflect and cause others to reflect on and transform their own everyday practices in response to their narration of own experience or the experience of others.

In the analysis of the (re)storied narratives (of construction workers) by first-year students, I was interested in both content and form and how the students' narrative constructions conform to or resist dominant discourses. My ultimate aim was to explore the possible changes in the students' conceptions regarding the knowledge and values contributed to the building industry by workers at the lower end of the professional spectrum.

\section{Setting}

A major assignment for a first-semester core module on Building Science in the BSc programme in Construction Management at a large residential university in Gauteng requires students to write a comprehensive report on a site visit. Students have to identify a suitable construction site to visit once or more weekly. The construction activities have to be documented by taking notes, making drawings, taking photographs and interviewing the builder, project manager, architect, contractor and general workers. They also need to consult a variety of primary sources on building construction and integrate the primary and secondary data. 'Correct use of reference techniques', 'Proper use of language and spelling' and 'Professional layout' as additional requirements are also demanded (Department of Construction Economics 2013).

An adjunct module, Academic and Professional Literacy for Construction Economics, provides cognitive as well as communicative scaffolding for the compilation of the report. When assessing students' site visit reports during 2013, I found very little evidence of social and communicative interaction on site. Students seldom reported on interviews, especially with general workers and artisans. Therefore, it was decided to include an assignment in the academic and professional literacy curriculum that would create space for students to interact with workers who may be overlooked as sources of knowledge and experience. Each small group of three to five students had to interview at least one worker on their career history, transcribe the interview, convert it to a narrative essay and reflect on how the interview had changed their perceptions about workers in the construction industry.

\section{Study population and sampling strategy}

The population comprised students registered for BSc programmes in Quantity Surveying, Construction Management and Real Estate and who were simultaneously registered for an adjunct module in academic and professional literacy in 2014. The sample consisted of 65 students, who constituted themselves in groups of 3-5 (17 groups). Each group chose a particular construction site for their research. The sample was both convenient and purposive, in that I fulfilled the 
roles of both course designer and lecturer. Approximately $50 \%$ were white students, while the other half comprised black students, mixed-race students and Asian students.

The construction workers were purposively sampled during one of the students' weekly visits. The interviewees comprised 15 black workers and 2 Asian workers. A third of the black interviewees (5) had not completed school or received any career training, two had limited practical training (a heavy vehicle driver's license and a certificate to operate excavating equipment, respectively), six occupied supervisory positions (stock managers, foremen and site managers) without having obtained a National Senior Certificate (NSC) and two were self-employed subcontractors who had improved their skills through practice training, and eventually became entrepreneurs. Both the Asian interviewees had at least an NSC qualification.

\section{Data collection}

The following set of questions was provided to the students as a guideline for structuring their interviews with the workers:

- Please share (tell us) your name, and what your trade is called. Please also describe your duties and responsibilities.

- Where did you grow up, and which school did you attend?

- Where did you start your work as an X (carpenter, bricklayer, plumber, etc.)?

- Were you trained to do this work? If you were, what kind of training did you receive?

- Please tell us about the people who played important roles in your training or your working career (some may have helped you, and others may have made it difficult for you to get ahead).

- What do you enjoy most about your job?

- What challenges do you face on a daily basis?

- What have you done/achieved in your career as an X that you are proud of?

- What changes have you seen in your trade/working conditions over the years, and what changes would you like to see in the future?

- What is your advice to someone interested in becoming an X (plumber, carpenter, etc.)?

- Is there anything else you want to tell us?

All interviews had to be transcribed, and a narrative essay of approximately 750-1000 words (based on the interview data) had to be written. The introduction was to contain a contextualising sentence to introduce the interviewee, a thesis statement and an outline of the main points of the essay. To write the body of the essay, students had to read through their notes and listen to the recording of the interview, write down three or five main themes or ideas related to the identity of the worker that featured prominently during the interview and write a chronological narrative with main ideas and supporting detail, making sure that the body paragraphs supported the thesis statement. It should be noted that the freedom to select salient topics introduced inherent 'data loss' in the procedure. The essay had to be concluded by 'a critical reflection on new meaning' that the students constructed for themselves by listening to the interviewees, for example, how their perceptions about people in certain categories of jobs may have changed, and how they might act differently when engaging with the workers (as managers) on site in the future.

The recordings and the transcripts had to be submitted together with the essays. If the interview was conducted in a language other than English or Afrikaans, an English translation of the transcript had to be produced. A research assistant was appointed to check the accuracy of the transcripts against the recordings. However, in some instances, the quality of the sound files was very poor, and eventually, the transcripts were the only evidence of the full scope of the raw data.

\section{Ethical considerations}

Written permission to use students as data gatherers and respondents was obtained from the Head of the Department of Construction Economics, the Dean of the Faculty of Humanities, the Dean of the Faculty of Engineering and the Built Environment and the Registrar of the University. Thereafter, ethical clearance for the project was obtained from the Research Ethics Committee of the Faculty of Humanities.

Students had to obtain written consent from the interviewees on site to conduct the interviews and to use the interview data for research purposes. In turn, all the students had to submit a signed letter of consent to allow the analysis of their narratives by the researcher. In total, 17 narratives, accompanied by the original sound or video recordings, were submitted.

\section{Data analysis}

Firstly, the narratives were read individually and annotated in the margins. Linguistic items that drew my attention mostly lexical features and direct quotes - were underlined. This assisted me in recording my initial impressions, which I developed into coding categories. The emerging codes were entered into the 'code manager' of the software program AtlasTi, version 7. Fundamentally, grounded theory analysis principles were used (Strauss \& Corbin 1990) to perform the content analysis. After coding the narratives, the codes were clustered together into themes on the basis of similarities. Output queries were generated for each family, listing all the quotes under each code in the family.

\section{Results and discussion Narrative analysis}

From the qualitative content analysis of the workers' narratives, four broad themes emerged: personal 
characteristics, sponsors/enablers, challenges and agency. A fifth theme, informal apprenticeship, partially overlaps with sponsors. These themes will be discussed by referring to the codes or primary categories they comprise. Quotes will be supplied to support the salience of the codes within the themes. In all instances, pseudonyms will be used to protect the anonymity of the respondents and third persons mentioned in their responses.

\section{Personal characteristics}

Generally, the interviewees were construed in a positive light. The students highlighted the following personality and character traits: ambition, diligence, thirst for knowledge, job satisfaction (joy/passion), motivation, problem-solving attitude, pride in work achievements, professionalism and reliability. The four characteristics that featured particularly prominent are job satisfaction, thirst for knowledge, diligence and ambition.

The notion of job satisfaction is primarily construed through the use of lexical items and phrases with positive values, such as at ease, enjoy, love and passionate. Sipho is said to be 'at ease with his working environment'; Samson's own words are quoted as 'Being a builder is not a job everyone prefers, but it is something I love'; Vuyani is reported to be 'very passionate about construction; and a person can tell this by just talking to him about his site and the project he works on'. The possessive form 'his site' construes Vuyani as experiencing ownership and a sense of belonging.

Workers' thirst for knowledge is construed by the students in $50 \%$ of the narratives. Their choices of words reflect the interviewers' admiration of this trait. Piet is construed as follows: 'he considers each day as a new chance to learn'; Johnson's goal is to 'constantly gather information to expand his knowledge'; Tsietsi's optimal goal 'is to expand his current knowledge about all the different trades practiced on the site'; Ruben's 'passion for the built environment is shown by his dedication to improve his skills'; and Tonderai is 'hard working and motivated to learn more'.

Judged by the way that students portray certain workers, hand (diligence) and heart (passion and joy) operate in close relation to each other. About Nelson, it is said that ' $[$ he $]$ enjoys his job very much' and 'he would encourage any hardworking person who needs an income to consider it'. Elias is quoted as an authority, when they report his conviction that 'diligence and passion are key factors of success in the built environment'.

Across culturally diverse groups, students admired the ambition demonstrated in the workers' responses to the interview questions. Some are portrayed as expressing the desire to be promoted, improve their qualifications, learn another trade, earn a better income or even establish their own construction company; whereas others are portrayed as already having made career progress through their ambition. It is interesting to note the predictions of success that some of the student groups make on the basis of their observations:
'Elias is full of hope, and looking at the way he has come, it's easy to see he is going to make something great out of his life.' [author's emphasis]

and:

‘He wants to be a contractor one day with his own company and an estimated team of a 100 people. Joseph has big dreams for the future and with his determination nothing would be able to stand in his way!' [author's emphasis]

\section{Sponsors/enablers}

The term 'sponsor' has been derived from the work on literacy narratives by Barton and Hamilton (2000). These authors use the term with regard to people who have contributed towards the literacy development of the storyteller or narrator. In the present article, the thematic label 'sponsors' is used to refer to people who had played significant roles in the career development of the workers who were interviewed. This theme is populated by the codes manager, father, friends and lives with nuclear family. Manager and father converge on the theme informal apprenticeship. Through the encouragement, motivation and benevolence of fathers and managers, and in one instance friends, the worker learnt either new trades or managerial skills on site through observing others, informal instruction and being entrusted with more responsibilities.

It is surprising that fathers would have had such a strong formative influence on their sons, particularly in light of the dominant discourse of absent fathers in black communities. One student group wrote about a construction worker who had improved himself to the level of a site manager: 'His dad was a great master not only as a father but also as an educator in the building trade'. Another group relate the story of Tsietsi, who was born in the Limpopo Province and 'spent his young life attending middle school and working for his father as a mechanic'. In yet another narrative, the group sings Piet's praises and almost exaggerates his father's contribution to his career: 'All the knowledge and experience he gained was contributed by his father's experience in the construction industry'. This may reveal a tendency that aptitudes, skills and interests are passed on from one generation to the next.

In five narratives (three written by predominantly black groups and two by predominantly white groups), the students emphasise the benevolence, foresight and facilitating role of managers, which served as catalysts in the careers of the construction workers - often after they had entered the industry through the inspiration of their fathers. This holds true for Tsietsi's career story, where 'The second big influence is his manager at [D]elta who sent him on the training course', and then later 'Last but not least his current boss [has] a massive influence, and aspires [sic] him to greater heights'.

A discourse that still dominates in many communities is that black workers are treated poorly by white managers. For example, on 24 December 2013, Vincent Masoga, National 
Media Officer of SATAWU (the South African Transport and Allied Workers' Union), writes: 'Workers, majority black, still remained treated as slaves and undignified minions of repressive white bosses in this democratic dispensation' (Masoga 2013). Contrary to this discourse, I found that the narratives construe relationships between white managers and black workers as healthy and cordial and provide ample evidence of workers' appreciation of the opportunities that their managers afforded them. The word opportunity and its plural occur 12 times in the narratives, mostly in connection with their work under the guidance of a particular manager, for example: 'gave him an opportunity to do a two month building course known as the EPWP'; 'offered him a job as ...'; 'sent him on a training course'; 'saw he had a natural talent with excavators and TLBs and took over his contract'; 'the company that he worked for sent him on to school through an organization called Shadayim'; 'He was granted the opportunity to come work at a company as the driver'; 'He dived in head on in his first and current employer Mr Venter. It was a huge risk for Mr Venter to entrust [sic] an unskilled worker with such a responsibility and Mr Mbuli acknowledged that'.

The pertinence of the code living with nuclear family, as a predictor of career success (which includes work-home balance in addition to a steady and sustainable income, recognition and autonomy), was unexpected. For instance, it was surprising to read the following about a Zimbabwean worker:

'Growing up in Zimbabwe, Tinashe dreamed of coming to South African to provide for his family. With a wife and two children living in Zimbabwe would not have given them the life they deserved. That is why he and his family moved to South Africa. [...] Compassionately [sic] he spoke of his wife and children and their life here in South Africa.'

The fact that four of the essays provide evidence of stable nuclear families constituting a support system for breadwinning workers run counter to the almost universal myth of black men fathering children and then abandoning them and their mother (Coles \& Green 2009).

\section{Challenges}

According to Ncwadi and Dangalazana (2005), the construction industry in South Africa is characterised by temporary and insecure employment and poor working conditions, which they largely attribute to conditions created under apartheid. Under apartheid laws, such as the Group Areas Act, groups within the construction industry became racially homogenous: The majority of mixed-race people became artisans, while black people were marginalised in terms of education and skills and remained labourers.

Given the dominant discourse of low wages and unacceptable working conditions in the construction industry, I anticipated that the interviewees without formal qualifications would dwell on the many challenges they had to face. However, contrary to my expectations, structural challenges do not feature prominently in their narratives. Although more than half of the interviewees indicated that they had not completed school, they are not construed as laying blame on any person or institution. Compare, for instance, phrases such as 'circumstances forced him to make decisions in order to provide for his family'; 'He attended three schools in his early days but he did not complete his schooling career'; 'Life became so expensive and it was difficult for me to continue with my studies' (direct quote from the interview). This focus on the outcome rather than its causes may be ascribed to the workers' assessment of what is appropriate to convey in an interview with young strangers from the middle class or it may be a construal of the students' subconscious guilt about their own positions of privilege.

Other challenges mentioned by the black workers include unstable childhood, hard physical labour, inadequate remuneration and struggle to find employment. The mentioning of these challenges is usually followed by a description of how the particular barrier was overcome through the agency of the interviewee, which is the next theme to be discussed.

\section{Agency}

The theme agency functions as an effect of the causal themes personal characteristics and sponsors/enablers, whereas challenges stand in a functional relationship of 'despite $\mathrm{x}, \mathrm{y}$ occurred'. The theme agency is constituted by two codes: overcoming challenges and seizing opportunities.

One of the stories about overcoming challenges is that of Johnson, who lives in Mpumalanga with his wife and two daughters (his two sons are already employed). He commutes between Mpumalanga and Pretoria on a daily basis, using the Putco bus service (the cheapest bus service available in major cities and towns in South Africa, used exclusively by black people from the working class). About this sacrifice, the students wrote: 'He has no problem balancing his daily work with his influence as a father at his house, since he loves being in charge at site and at home'. Piet Matipa, another worker who has managed to progress from general construction worker to foreman, finds his new position challenging, but is portrayed as in command and capable of solving all problems at hand: 'It is his first time working as the only foreman on site. He seems to be managing well and occasionally gets called by his subordinates as they need his help'.

A precursor of agency is a conscious or unconscious decision to take responsibility for your own life and desiring to change your circumstances volitionally. Such changes are often the result of seizing opportunities. As mentioned earlier, the word 'opportunity' occurs frequently in the narratives. In the majority of instances, the sponsor is the worker's line manager or father. It seems natural for a father to pass his trade on to his son.

The themes informal apprenticeship and agency are bidirectionally related. Having acquired skills through an apprenticeship builds self-confidence, which leads to 
agency. Agency, on the other hand, could make an informal apprenticeship successful through willingness to learn from experienced others. I assigned the code seizing opportunities 14 times - whenever the text provided clear evidence of volition on the part of the construction worker; for instance, when a noun or pronoun referring to the worker as the subject of an active sentence. The pronoun is usually combined with an action verb, such as in 'He began his journey as a stock manager in the year 2002 with no prior skills or knowledge of the task. He dived in head on in his job [...]'; and 'At age 20 he applied for a job at Delta mechanics'. The use of direct quotes strengthens the agentive focus, as in 'I saw an opportunity in scaffolding, because everyone was scared of it. I am a person who is not scared of challenges'.

\section{Summary of the narrative findings}

Pavlenko (2007:167) advises narrative researchers ' $[t] \mathrm{O}$ provide analysis that goes beyond a list-making activity' and to adopt a specific theoretical framework that allows clarification of the nature of the conceptual categories as well as clarify the links between themes. I offer Figure 1 as a schematic representation of the grounded theory that precipitated from the analysis of the student narratives.

The schematised results of the content analysis point to agency as the primary determinant of career success in the lives of construction workers. Agency, in turn, is catalysed by three main factors: personal characteristics, sponsors and informal apprenticeships, provided to them by some of the sponsors. On the other hand, agency may be potentially inhibited by challenges, if they are not resisted or managed. Contrary to my expectations, I observed no marked differences between the narratives of groups comprising predominantly white or black students. The themes that precipitated occurred across the narratives written by different cultural groups.

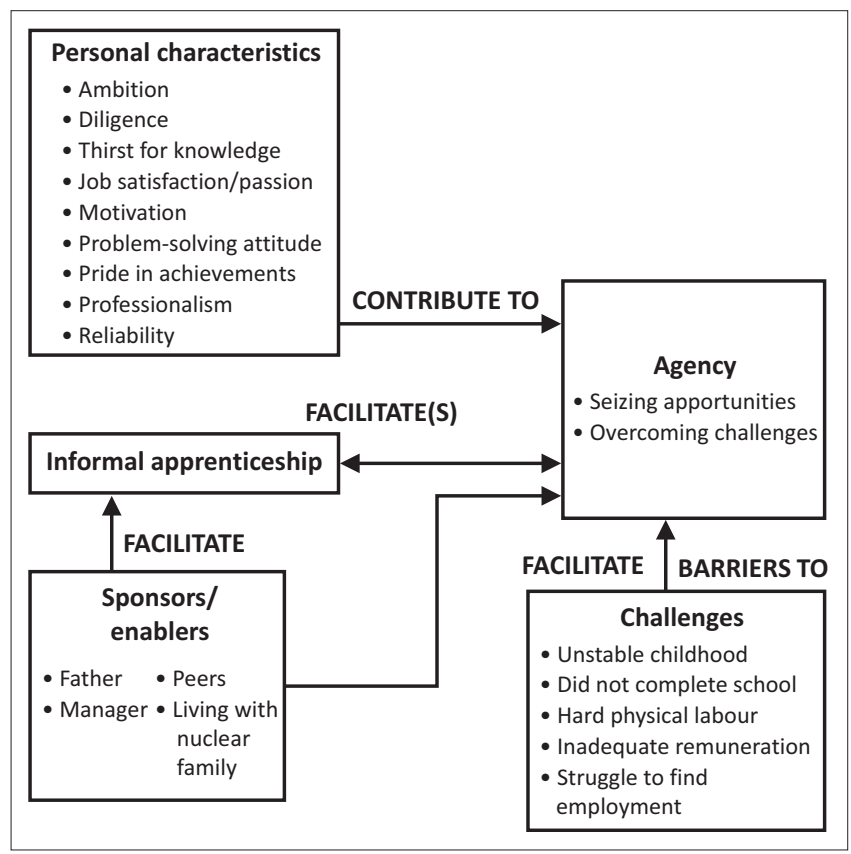

FIGURE 1: Codes, themes and relationships on worker identities emerging from the data.
I now turn to what students perceived to have learnt through the interviewing and writing of the narratives.

\section{Analysis of students' critical reflections}

Critical reflection occupies a central place in models aimed at improving intercultural understanding and in consciousnessraising practices (Freire 1970). It also gives learners a sense of ownership over meaning making (Norton 2010). The student groups comprising the sample in the study had to conclude their essays by means of a critical reflection on how their views of construction workers have changed as a result of the interviewing and writing of the third-person career narratives. Two themes feature prominently in the students' reflections. The first is Circumstances do not determine career success. The following quotes instantiate this theme:

1. 'This tells us that the challenges that we are facing now does [sic] not define our future success.'

2. 'Thabo is a great example of someone who rose above their circumstances and made life better for themselves and their families.'

3. 'Coming from a disadvantaged background should not be your limitation.'

4. 'Our interview with Samson taught us that you don't always have to have the highest qualifications to be happy and enjoy your job.'

From a social literacies perspective (Gee 1996; Street 1995; New London Group 1996), it can be asserted that students arrived at an understanding that literacy is not a prerequisite for social mobility and progress and that 'literacy practices specific to the political and ideological context and their consequences vary situationally' (Street 1995:24).

The second theme that emerged from students' reflections on what they had learnt is that diligence and work ethics are the most important determinants of career success. Instantiations of this theme include the following:

1. 'There is [sic] no shortcuts to success.'

2. 'He [Samuel Motupi] teaches us that the only road to success is hard, hard, hard work.'

3. 'Piet teaches us that with hard work and determination we can succeed in this field.'

4. 'What truly matters is the unquenchable thirst for knowledge and hard work to build your dreams into reality.'

5. 'It is important to always stay professional especially in the built environment, and be clinical [sic] in everything you do.'

Thus, in general, the students regarded personal dispositions (work ethics) and diligence as determinants of success. When comparing the students' reflections with the findings from the qualitative content analysis, important overlaps could be observed. However, I realised that I had overlooked the outcome of satisfying work endeavours: success, which was then added to the theoretical model, as indicated by Figure 2. 


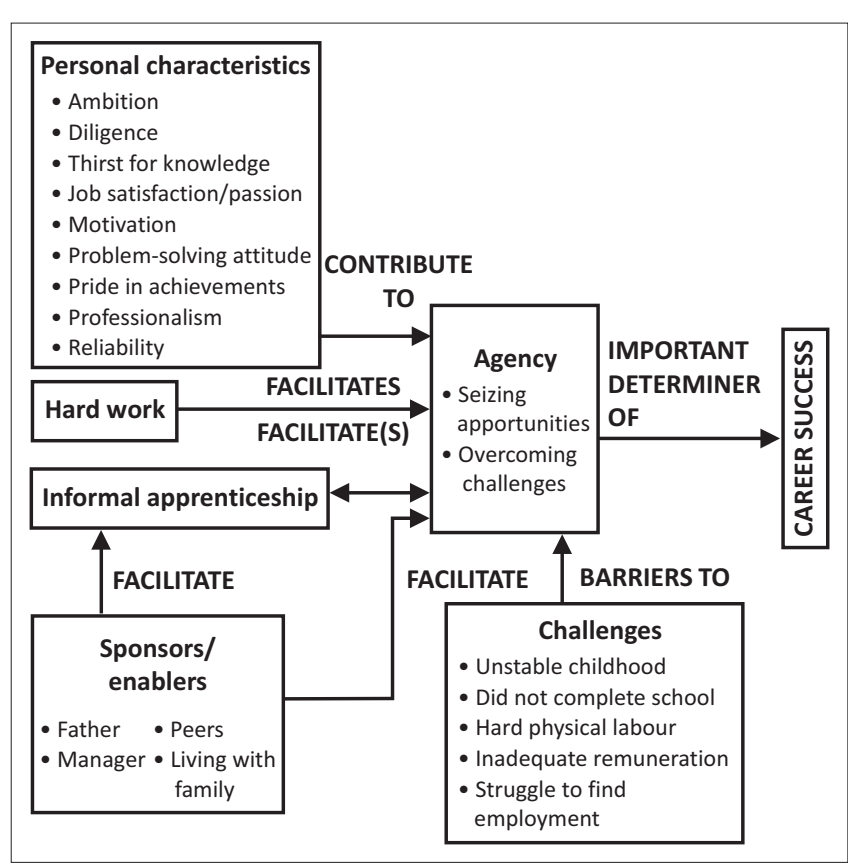

FIGURE 2: Addition of 'career success' to the theoretical model on worker identities derived from the analyses of the student narratives.

\section{Conclusion}

Conclusions may be drawn regarding the effectiveness of the pedagogy of narrative analysis as well as the results of analysing the student narratives and the students' reflections on the process of narrative knowledging. Regarding the pedagogy of narrative re-storying, evidence was provided that the learning experience engaged students in a critique of knowledge production and assisted them to (re)negotiate their own identities in relation to others in the building industry.

Secondly, the researcher's analyses of the student narratives indicated that agency is the most important predictor of success for construction workers. Agency, in turn, is driven by personal characteristics and the roles that significant others have played in offering opportunities, such as informal apprenticeships. However, agency may be constrained by challenges that are either not resisted or not managed. This is indeed a positive finding, which powerfully negates the stereotype of black South African workers as an ignorant majority that lacks the personal dispositions to get ahead in life, as well as the self-awareness to assess gaps in their knowledge, skills and abilities and seek to improve themselves accordingly. What all students of construction economics may take from these results is the importance of identifying and developing employees' personal strengths and providing them with opportunities, both formal and informal, for career advancement. On the other hand, future managers should be sensitised to the common barriers to career success and job satisfaction. Where possible, the barriers or the potential causes of harm should be removed; and where the effects have already occurred, they should be managed and mitigated.

Finally, the analysis of students' critical reflections on what they had learned and how their perceptions of workers had changed demonstrates a realisation that successful workers are driven by an internal locus of control and are not derailed by adverse circumstances. Contrary to common stereotypical beliefs about black workers, the majority of the interviewed workers were self-reflective individuals who overtly ascribed success to work ethics. One (white) student acknowledged that before given this assignment he had thought that Black Economic Empowerment was one of the worst nightmares to face him as a construction manager. Before embarking on the interview assignment, he was convinced that workers' laziness and lack of ambition were the major stumbling blocks in running a profitable construction business.

A limitation of the research was the duration of the academic literacy module (one semester), which did not allow me to probe whether students' transformed perceptions translated into transformed practice. A further limitation is linked to the research design. When researchers (in this case the students) restory others' narratives, they are imposing meaning on these persons' lived experience. Bell (2002:210) cautions that the effects of such 'imposed restorying' can be powerful. Future research should involve triangulation, for example, by administering attitude surveys preceding and following interviews with workers and retelling their career stories. This methodology would facilitate a more accurate picture of the changes that have occurred in students' critical multicultural awareness as a result of their interaction with workers and their critical reflection on their own reconstructed narratives. On the pedagogical side, in order to deliver well-rounded graduates to the construction industry, multiple opportunities should be created in the curricula for modules focused on the acquisition of ' hard' as well as 'soft' skills. A method to teach diversity skills, which has been applied successfully in other subject-specific academic literacy modules, is to engage students in the reading of and reflecting on oral, written or multimodally presented personal career narratives by professionals from different cultural, gender and age groups.

\section{Acknowledgement}

The contribution of Ms Linda-Anne Alston in planning the narrative assignment and providing feedback on the interview questions as well as the first draft of the article is duly acknowledged.

\section{Competing interest}

The author declares that she has no financial or personal relationship(s) which may have inappropriately influenced her in writing this article.

\section{References}

Ahn, Y.H., Annie, R.P. \& Kwon, H., 2012, 'Key competencies for US construction graduates: Industry perspective', Journal for Professional Issues in Engineering Education and Practice 138(2), 123-130. http://dx.doi.org/10.1061/(ASCE) El.1943-5541.0000089

Barkhuizen, G., 2013, 'Introduction: Narrative research in applied linguistic', in G. Barkhuizen (ed.), Narrative research in applied linguistics, pp. 1-16, Cambridge University Press, Cambridge.

Barton, D. \& Hamilton, M., 2000, 'Literacy practices', in D. Barton, M. Hamilton \& R. Ivanic (eds.), Situated literacies: Reading and writing in context, pp. 7-15, Routledge, London. 
Bell, J.S., 2002, 'Narrative inquiry: More than just telling stories', TESOL Quarterly 36(2), 207-218. http://dx.doi.org/10.2307/3588331

Bilbo, D., Fetters, T., Burt, R. \& Avant, J., 2000, 'A study of the supply and demand for construction education graduates', Journal of Construction Education 4(1), $54-65$

Boje, D.M., 1991, 'The storytelling organization: A study of story performance in an office-supply firm', Administrative Science Quarterly 36(1), 106-126. http://dx. doi.org/10.2307/2393432

Boyle-Baise, M. (ed.), 2002, Multicultural service learning: Educating teachers in diverse communities, Teachers College, Columbia University, New York.

Bruner, J.S., 2006, In search of pedagogy Vol II: The selected works of Jerome S. Bruner, Routledge, London.

Clandinin, D.J. \& Connelly, F.M., 2000, Narrative inquiry: Experience and story in qualitative research, Jossey-Bass, San Francisco, CA.

Coles, R. \& Green, C. (eds.), 2009, The myth of the missing Black father, Columbia University Press, New York.

De Fina, A. \& Georgakopolou, A., 2012, Analysing narrative: Discourse and sociolinguistic perspectives, Cambridge University Press, Cambridge.

Department of Construction Economics, 2013, BWT 110 building science, study guide, University of Pretoria, Pretoria.

Denzin, N.D. \& Giardina, M.D. 2009, 'Introduction: Qualitative inquiry and social justice - Toward a politics of hope', in N.K. Denzin \& M.D. Giardina (eds.) Qualitative inquiry and social justice: Toward a politics of hope, pp. 11-50, Left Qualitative inquiry and social justic
Coast Press, Walnut Creek, CA.

Eyler, J. \& Giles, D.E., 1999, Where's the learning in service learning?, Jossey-Bass, San Francisco, CA.

Freire, P., 1970, Pedagogy of the oppressed, transl. M. Bergman Ramos, Herder \& Herder, New York.

Gee, J., 1996, Social linguistics and literacies: Ideologies in discourse, Taylor \& Francis, London.

Einfeld, A. \& Collins, D., 2008, 'The relationships between service-learning, social justice, multicultural competence, and civic engagement', Journal of College Development 49(2), 95-109. http://dx.doi.org/10.1353/csd.2008.0017

Hager, P., Crowley, S. \& Garrick, J., 2000, 'Soft skills in the construction industry: How can generic competencies assist continuous improvement', paper presented at the annual Conference of the Australian Association for Research in Education the annual Conference of the Australian Assoc
University of Sydney, 4-7th December, 2000.

Kubota, R., 2004, 'Critical multiculturalism and second language education', in B. Norton \& K. Toohey (eds.), Critical pedagogies and language learning, pp. 30-52, Cambridge University Press, Cambridge.

Leung, J.K.L. \& Fong, P.S.W., 2011, 'The power of stories in the construction industry', VINE: The Journal of Information and Knowledge Management Systems 41(4), 466-482. http://dx.doi.org/10.1108/03055721111188548

Lieblich, A., Mashiach-Tuval, R. \& Zilber, T., 1998, Narrative research: Reading, analysis and interpretation, Sage, Thousand Oaks, CA.

Mahasneh, J.K. \& Thabet, W., 2015, 'Rethinking construction curriculum: A descriptive cause analysis for the soft skills gap among construction graduates', in 51st ASC Annual International Conference Proceedings, viewed 11 March 2016, from ascpro0.ascweb.org/archives/cd/2015/paper/CEUE391002015. pdf

Masoga, V., 2013, 'Satawu Christmas and new year message to transport and allied workers', viewed 30 November 2014, from https://www.facebook.com/ permalink. php? story_fbid $=561479743945093$ andid $=101790993247306$ andstre am_ref=10
Meyer, E., 2004, 'A narrative approach to knowledge management: An investigation into the use of narrative as a medium to knowledge transfer in small teams', PhD thesis, University of Southampton.

Ncwadi, M.R. \& Dangalazana, T., 2005, 'An exploratory study into the challenges facing the emerging contractors involved in the construction of low cost housing in Wells Estate and Ikamv'elihle Townships in the Nelson Mandela Metropole, South Africa', paper presented at the World Congress on Housing: Transforming Housing Environments through Design, Pretoria, 27-30th September, viewed 10 May 2014, from http://repository.up.ac.za/bitstream/handle/2263/10372/An\%20 Exploratory $\% 20$ Study $\% 20$ into $\% 20$ the $\% 20$ Challenges $\% 2$ Facing $\% 20$ the $\% 20$ Emerging.pdf

New London Group, 1996, 'A pedagogy of multiliteracies. Designing social futures', Harvard Educational Review 66, 60-29. http://dx.doi.org/10.17763/haer. 66.1.17370n67v22j160u

Norton, B., 2010, 'Identity, literacy, and English-language teaching', TESL Canada Journal 28(1), 1-7. http://dx.doi.org/10.18806/tesl.v28i1.1057

Ochs, E. \& Capps, L., 2001, Living narrative: Creating lives in everyday storytelling, Harvard University Press, Cambridge.

Othman, A.A.E., 2014, 'A study of the competency requirements of property development graduates to meet qualifications of the South African Construction Industry', Journal of Engineering, Design and Technology 12(1), 2-28. http:// dx.doi.org/10.1108/JEDT-04-2012-0019

Pavlenko, A., 2007, 'Autobiographic narratives as data in applied linguistics', Applied Linguistics 28, 163-188. http://dx.doi.org/10.1093/applin/amm008

Polanyi, L., 1989, Telling the American story, MIT Press, Cambridge, MA

Polkinghorne, D.E., 1995, 'Narrative configuration in qualitative analysis', Qualitative Studies in Education 8, 5-23. http://dx.doi.org/10.1080/0951839950080103

Rhoads, R.A., 1995, 'Critical multiculturalism, border knowledge, and the canon: Implications for general education and the academy', The Journal of Genera Education 44(4), 256-273.

Rubdy, R., 2009, 'Reclaiming the local in teaching ESL', Language and Intercultural Communication 9, 156-174. http://dx.doi.org/10.1080/14708470902748822

Shakir, R., 2009, 'Soft skills at the Malaysian institutes of higher learning', Asia Pacific Educational Review 10, 309-315. http://dx.doi.org/10.1007/s12564-009-9038-8

South African Council for the Project and Construction Management Professions (SAPCMP), n.d., Project and Construction Management Programmes, SAPCMP, Midrand.

Steier, F., 1991, 'Introduction: Research as self-reflexivity, self-reflexivity as social process', in F. Steier (ed.), Research and reflexivity, pp. 1-11, Sage, London.

Strauss, A. \& Corbin, J., 1990, Basics of qualitative research: Grounded theory procedures and techniques, Sage, Newbury Park, CA.

Street, B., 1995, Social literacies: Critical approaches to literacy in development, ethnography and education, Longman, London.

Sunindijo, R.Y. \& Zhou, P.X.W., 2013, 'The roles of emotional intelligence, intepersonal skill, and transformational leadership on improving construction safety performance', Australasian Journal of Construction Economics and Building 13(3), performance', Australasian Journal of Construction Econ

Tobin, P.K.J., 2006, 'The use of stories and storytelling as knowledge sharing practices: A case study in the South African mining industry', PhD thesis, University of Pretoria.

Van Heerden, H., 2016, 'Personal communication on the growing importance of soft skills in the construction industry', University of Pretoria, 16 March.

Wilson, E., 2013, Construction needs soft skills in a tough culture, viewed 28 August 2016, from http://www.constructionmanagermagazine.com/management/ construction-undermining-foundations-leadership-de/ 